Maarten J. Aalders

\title{
Recente congressen en publicaties over de kindertreinen
}

Op 6 en 7 februari 2020 vond in Kampen (NL) een internationaal congres plaats over de kindertreinen en wat daar op volgde: De kindertreinen en verder - Culturele, religieuze en politieke betrekkingen tussen Hongarije en de Lage Landen in het interbellum. Dit congres kan beschouwd worden als een vervolg op de conferentie die op 8 november 2018 aan de ELTE plaatsvond. Dat was de eerste maal dat er op wetenschappelijk niveau aandacht werd besteed aan de kindertreinen. Deze bijeenkomst in Kampen was daarop een vervolg.

Het congres in Boedapest werd georganiseerd door de vakgroep Neerlandistiek van de ELTE, in het bijzonder door dr. Orsolya Réthelyi. Er waren sprekers uit binnen- en buitenland, er was een tentoonstelling over de kindertreinen. In de loop der jaren had dr. Réthelyi allerlei materiaal verzameld over dit thema, dat ter gelegenheid van dit congres werd tentoongesteld. Ook was er een muzikaal programma en Een bijzondere vrouw, het toneelstuk van Rudi Hermans werd opgevoerd. Studenten van dr. Réthelyi werden bij het project betrokken omdat zij de beschrijvingen verzorgden bij de tentoongestelde stukken, zowel in het Hongaars als in het Nederlands. Dit werd later opgenomen in de tentoonstellingscatalogus die eind 2018 in druk verscheen, onder redactie van Réthelyi en Aalders.

Maar hierbij bleef het niet. De kindertreinen hebben een enorme impact gehad. Natuurlijk allereerst op het leven van de kinderen, hun ouders en hun gastouders. Maar de uitstraling was veel groter. Vandaar 
dat er een vervolg-congres nodig was, dat in 2020 werd georganiseerd met medewerking van professor dr. George Harinck, hoogleraar aan de Vrije Universiteit en aan de Theologische Universiteit in Kampen. Opnieuw waren er sprekers uit binnen- en buitenland. De eerste dag reeds werd de congresbundel De Hongaarse kindertreinen - Een levende brug tussen Hongarije, Nederland en België na de Eerste Wereldoorlog, geredigeerd door Aalders, Pusztai en Réthelyi gepresenteerd, in het Nederlands. Een week later vond in Boedapest de presentatie van dezelfde congresbundel in het Hongaars plaats. Wie iets over de kindertreinen wil weten of schrijven, kan niet om deze bundel heen. Vooral niet om de artikelen van Vera Hajtó en Maarten J. Aalders. De eerste schreef over de kindertreinen die naar België reden, de tweede over de treinen die naar Nederland reisden. Hier werd de kern van de kinderactie zowel in het Nederlands als in het Hongaars beschreven, berustend op grondig archiefonderzoek.

Met de presentatie van deze congresbundel uit 2018, in bijzijn van René van Hell, Nederlands ambassadeur in Boedapest, en András Kocsis, ambassadeur van Hongarije in Den Haag, werd duidelijk gemaakt dat het in Kampen niet over de kindertreinen zonder meer ging. Dit congres ging ook over wat daarop volgde, en dat was heel veel. Reeds in 1926 was dit door bisschop László Ravasz verwoord, toen hij de kindertreinen vergeleek met een 'schietspoel', een uitvinding die indertijd het weefproces bijzonder versneld heeft. Een relatief kleine uitvinding met ontzettend grote gevolgen. Dat zagen we op dit congres terug, en niet alleen in de titel: $D e$ kindertreinen en verder. De organisatie was in handen van The NeoCalvinism Research Institute van de Theologische Universiteit Kampen, de Vakgroep Neerlandistiek van de Eötvös Loránd Universiteit (ELTE), in samenwerking met de Ambassade van Hongarije in Nederland. Opnieuw, als in 2018, was Orsolya Réthelyi een stimulerende kracht, bijgestaan door Harinck en Aalders.

Nadat de conferentie was geopend door de rector magnificus Roel Kuiper en George Harinck het thema van de conferentie had geïntroduceerd, ging de aandacht uit naar de politieke en religieuze context van de kindertreinen, het eerste thema ('panel') van de zes die aan de orde zouden komen. Balázs Ablonczy vroeg aandacht voor de politieke strategie van Hongarije na de Eerste Wereldoorlog, Pál Hatos voor de rol van László Ravasz, en de Nederlandse geleerde Adriaan Overbeeke voor de kerkelijke gevolgen van het verdrag van Trianon. 


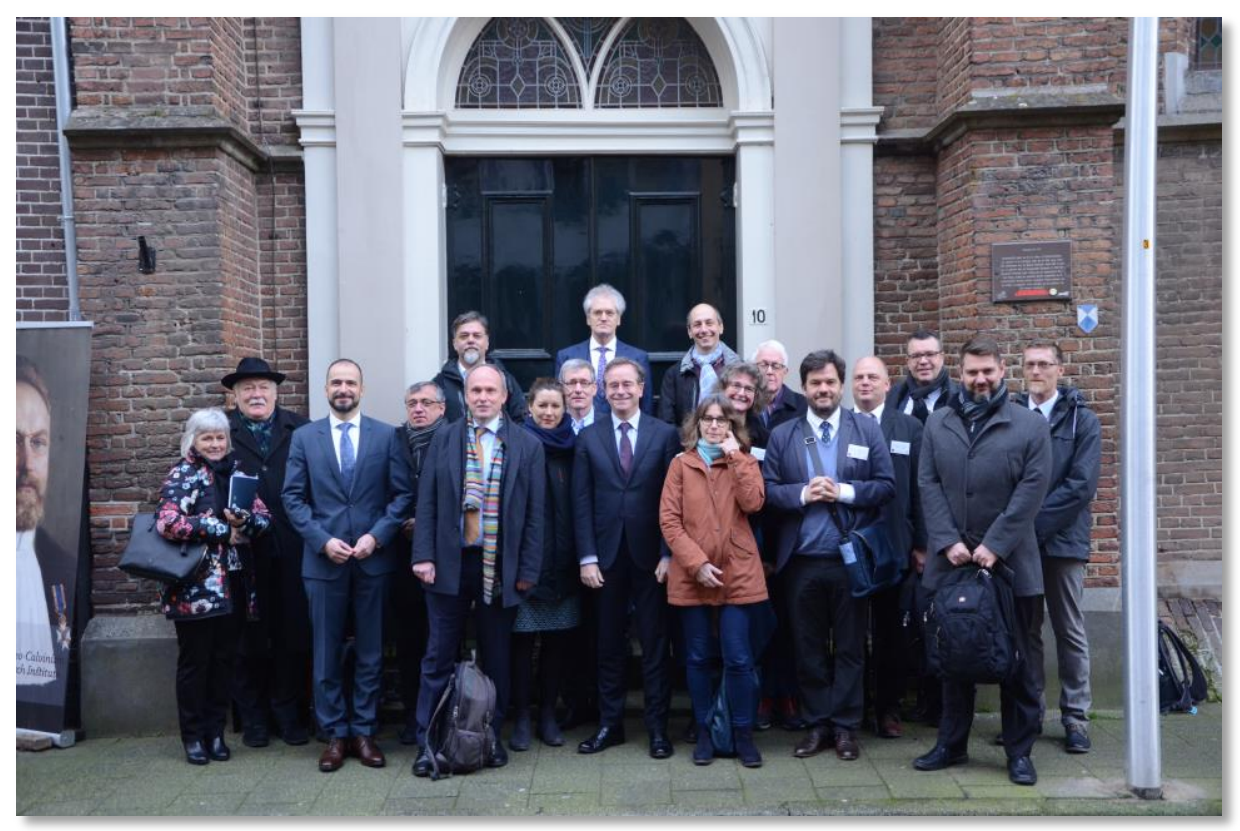

De deelnemers van het congres "De kindertreinen en verder" op 7 februari 2020 in Kampen.

Een ander thema was gewijd aan het thema kerk en politiek, waar Gábor Lányi en Ábrahám Kovács beiden spraken over Jenő Sebestyén en George Harinck een voordracht hield over aspecten van het neocalvinisme. In een ander panel werd de aandacht verlegd naar de culturele gevolgen van de kindertreinen. Zo sprak Orsolya Réthelyi over de gevolgen van de kindertreinen op het ontstaan van enkele Nederlandstalige literatuurgeschiedenissen van de Hongaarse literatuur.

Met deze conferentie werd niet alleen op een wetenschappelijk publiek gemikt, ook was er nadrukkelijk plaats gemaakt voor de 'nazaten' van de kindertreinkinderen die hier bleven. Hoeveel dat er precies zijn geweest, staat niet vast. Hajtó schat dat het in België ging om zo'n duizend kinderen die niet naar huis terugkeerden. Kamilla Mezősi, die twintig jaar geleden onderzoek deed naar de kindertreinen en daarover ook publiceerde, komt voor Nederland tot een schatting van 2000 à 3000 kinderen. Van hun nazaten waren er velen naar Kampen gekomen. Wellicht was het wetenschappelijk gehalte voor sommigen van hen af en toe wat hoog, maar zij kwamen zeker aan hun trekken: er was een rondetafelgesprek georganiseerd met een aantal nazaten, enkele liederen van de kindertreinen werden gezongen en het toneelstuk van Rudi Hermans over de lotgevallen 
van zijn Hongaarse moeder in België werd ook in Kampen opgevoerd. In de koffieruimte was de reizende tentoonstelling " A kis magyarok' Belga-magyar gyermekmentő akciók” (“"De Hongaartjes' - BelgischHongaarse kinderacties") te zien, samengesteld door Vera Hajtó in samenwerking met het KADOC Leuven en in het Hongaars vertaald door de leden van de vakgroep Neerlandistiek van de Debrecen Universiteit.

Het is duidelijk dat het besluit van Réthelyi om in 2018 aandacht te vragen voor de kindertreinen veel vrucht heeft gedragen. Er verscheen een catalogus en een boek, en ook van dit congres zal een bundel verschijnen. Bovendien heeft de internationale samenwerking een grote schrede voorwaarts gemaakt door de oprichting van de onderzoeksgroep Migratie, cultuur en identiteit, opgericht rond het thema van de Hongaarse, Nederlandse en Belgische kindertreinen en migratie. Naar mijn oordeel is het juist dit aspect van internationale collegiale samenwerking dat enorm heeft bijgedragen aan de bekendheid van de kindertreinen en hun gevolgen. In deze tijd, waarin de universiteit gezien wordt als een bedrijf, en de wetenschappelijke wereld als een markt, staat het onderlinge vertrouwen, en daarmee de samenwerking voortdurend onder druk.

\section{Bibliografie}

Aalders, Maarten J. en Orsolya Réthelyi (red.), De 'kindertreinen' Voorwerpen en herinnering. Tentoonstellingscatalogus bij de workshop Migratie, literatuur en identiteit. De 'kindertreinen' tussen Hongarije, Nederland en Vlaanderen in de eerste helft van de twintigste eeuw / A 'gyermekvonatok' - Tárgyak és emlékezet. A Migráció, irodalom és identitás: A "gyermekvonatok" Magyarország, Hollandia és Flandria között a huszadik század első felében címü workshop kiállitási katalógusa (Budapest 2018).

Aalders, Maarten J., Gábor Pusztai en Orsolya Réthelyi (red.), De Hongaarse kindertreinen. Een levende brug tussen Hongarije, Nederland en België na de Eerste Wereldoorlog (Hilversum-Budapest 2020).

Aalders, Maarten J., Gábor Pusztai en Orsolya Réthelyi (red.), A gyermekvonatok - Élö híd Magyarország, Hollandia és Belgium között az elsö világháború után (L’Harmattan Budapest 2020). 